\title{
Sertoli cell-secreted protein(s) stimulates DNA synthesis in purified rat Leydig cells in vitro*
}

\author{
J. O. Ojeifo, S. W. Byers, V. Papadopoulos and M. Dym \\ Department of Anatomy and Cell Biology, Georgetown University Medical Center, \\ 3900 Reservoir Road, N.W., Washington, D.C. 20007, USA
}

\begin{abstract}
Summary. We have examined the effects of Sertoli cell-secreted proteins (SCSP) on $\left[{ }^{3} \mathrm{H}\right]$ thymidine incorporation by purified preparations $(>96 \%)$ of rat Leydig cells to determine whether Sertoli cells influence DNA synthesis in these cells in vitro. Incubation of Leydig cells isolated from testes of rats of ages 16 to 90 days with SCSP $\left(M_{\mathrm{r}}>10000\right)$ induced significant dose-, time- and age-related increases in $\left[{ }^{3} \mathrm{H}\right]$ thymidine incorporation by the cells. A dose-response curve to SCSP showed that as little as $0 \cdot 2 \mu \mathrm{g} \mathrm{SCSP} / \mathrm{ml}$ consistently induced a small but significant increase $(31 \%$ and $10 \%$ above control; $P<0.001)$ in $\left[{ }^{3} \mathrm{H}\right]$ thymidine incorporation by Leydig cells isolated from immature (26 days) and mature (70 days) rats, respectively. The maximum response ( $230 \%$ and $48 \%$ above control) was obtained with a concentration of $18 \mu \mathrm{g} \mathrm{SCSP} / \mathrm{ml}$ in cells isolated from immature and mature rats, respectively. Hydroxyurea, a specific inhibitor of replicative DNA synthesis, significantly $(P<0.001)$ inhibited both basal and SCSP-induced $\left[{ }^{3} \mathrm{H}\right]$ thymidine incorporation in Leydig cells from immature and adult rats without affecting the viability of the cells. Incubation of immature rat Leydig cells in SCSP for $48 \mathrm{~h}$ also stimulated a 3 -fold increase in cell number. The component of the crude SCSP which stimulated Leydig cell $\left[{ }^{3} \mathrm{H}\right]$ thymidine incorporation is trypsinsensitive, heat-stable, and adsorbs to a heparin-agarose affinity column but not to concanavalin A-Sepharose. The secretion of this factor(s) by Sertoli cells is stimulated independently by FSH and testosterone. These results demonstrate for the first time that cultured Sertoli cells secrete a protein(s) which, in vitro, stimulates rat Leydig cell replicative DNA synthesis.
\end{abstract}

Keywords: testis; Sertoli cell; Leydig cell; DNA; rat

\section{Introduction}

It has long been recognized that the differentiation of Leydig cells from precursor cells and their proliferation is regulated by luteinizing hormone/human chorionic gonadotrophin ( $\mathrm{LH} / \mathrm{hCG}$ ) (de Kretser \& Kerr, 1988). In recent years, however, several studies have shown that the seminiferous tubules may also regulate the number of neighbouring Leydig cells. For example, Aoki \& Fawcett (1978) have demonstrated that experimental depletion of spermatogenic cells from the seminiferous tubules results in the hyperplasia and hypertrophy of Leydig cells in the vicinity of the affected tubules. It has also been reported that treatment of hypophysectomized immature rats with folliclestimulating hormone (FSH) resulted in an increase in the number of Leydig cells in vivo (Kerr \& Sharpe, 1985; Teerds et al., 1989). More recently, it was reported that hyperplasia of Leydig cells also occurs in the testes of men with germ cell tumours (Lauke et al., 1989). In all the patients, concentrations of plasma hormones were found to be normal and mitotic figures of Leydig cells were observed only in intertubular tissues that were adjacent to impaired seminiferous tubules,

*Reprint requests to Dr Martin Dym. 
while Leydig cells adjacent to neighbouring normal tubules showed no evidence of an increase in number.

As Leydig cells have no FSH receptors (Wahlstrom et al., 1983; Yoon et al., 1987), the stimulatory effect of FSH on Leydig cell number (Kerr \& Sharpe, 1985; Teerds et al., 1989) is probably mediated via Sertoli cells. These reports, together with the demonstration that Sertoli cell-secreted protein(s) stimulates DNA synthesis and proliferation of A431 and Swiss 3T3 cell lines (Bellve \& Zheng, 1989), raise the possibility that Sertoli cell-secreted product(s) may act as paracrine regulator(s) of Leydig cell DNA synthesis and, consequently proliferation. To test this hypothesis, we examined the effects of Sertoli cell-secreted proteins (SCSP) on $\left[{ }^{3} \mathrm{H}\right]$ thymidine incorporation in purified preparations of rat Leydig cells in vitro.

\section{Materials and Methods}

\section{Animals and chemicals}

Animals. Normal male Sprague-Dawley rats aged 16-90 days were used. The rats were purchased from Charles River Breeding Laboratories, Inc. (Wilmington, MA, USA) and housed in the Research Resources Facility at Georgetown University. They were kept 5 to a cage (polyprocarbonate; $20 \times 32 \times 55 \mathrm{~cm}$ ) under controlled temperature $\left(20-22^{\circ} \mathrm{C}\right)$ and light $(12 \mathrm{~h}$ light: $12 \mathrm{~h}$ dark $)$ conditions. They were fed a commercial laboratory chow and offered water ad libitum until experimentation was initiated at the appropriate ages.

Chemicals. Medium-199 (M-199), Hanks balanced salt solution (HBSS) and Dulbecco's phosphate-buffered saline (DPBS) were purchased from Gibco Laboratories (Grand Island, NY, USA), collagenase (CLSII, $168 \mathrm{U} / \mathrm{mg}$ ) from Worthington Biochemical Corporation (Frehold, NJ, USA), and Percoll from Pharmacia Inc. (Piscataway, NJ, USA). Chorionic gonadotrophin (CG-5), bovine serum albumin (BSA), N-2-hydroxyethyl piperazine-N-2 ethanesulphonic acid (Hepes), soybean trypsin inhibitor (STI), trypsin, mouse epidermal growth factor (mEGF), testosterone, oestradiol-17 $\beta$, ethylene-diamine-tetraacetic acid (EDTA), DNAse $1(2050 \mathrm{U} / \mathrm{mg})$, nitro-blue tetrazolium (NBT), aetio-cholan-3 $\beta$-ol-17-one, $\beta$-nicotinamide adenine dinucleotide $\left(\beta-\mathrm{NAD}^{+}\right)$, hyaluronidase $(660 \mathrm{U} / \mathrm{mg})$, sodium bicarbonate $\left(\mathrm{NaHCO}_{3}\right)$, collidine, osmium tetroxide $\left(\mathrm{OsO}_{4}\right)$, and concanavalin $\mathrm{A}-\mathrm{Sepharose} 4 \mathrm{~B}$ were obtained from Sigma Chemical Company (St Louis, MO, USA), while glutaraldehyde was purchased from Electron Microscopy Sciences (Ft Washington, PA, USA). Reagents for protein measurement and Aff-Gel heparin were purchased from Bio-Rad (Richmond, CA, USA). Insulin, transferrin, linoleic acid, and selenium premix $\left(\right.$ ITS $^{+}$) were purchased from Collaborative Research Inc. (Bedford, MA, USA); Ham's F12/DME was obtained from Irvine Scientific (Santa Anna, CA, USA). Ovine FSH (NIADDK-oFSH-17; $20 \mathrm{U} / \mathrm{mg}$ ) and (NIADDK-oLH-26; 2.3 U/mg) were gifts from the National Institute of Arthritis, Diabetes, and Digestive and Kidney Diseases (Bethesda, MD, USA). [Methyl- ${ }^{3} \mathrm{H}$ ]thymidine (sp. act. $67 \mathrm{Ci} / \mathrm{mmol}$ ) was purchased from ICN Radiochemicals (Irvine, CA, USA), anti-testosterone-7 $\alpha$-BSA serum was from ICN Immunobiologicals (Lisle, IL, USA) and a gift from Dr M. H. G. Raj (Louisiana State University, LA, USA) and $\left[1,2,6,7-{ }^{3} \mathrm{H}(\mathrm{N})\right]$ testosterone (sp. act. $93 \cdot 9 \mathrm{Ci} / \mathrm{mmol}$ ) was from New England Nuclear (Boston, MA, USA).

\section{Isolation of Leydig cells}

Leydig cells were isolated by using a modified version of the technique of Klinefelter et al. (1987). The rats were anaesthetized with pentobarbitone sodium $(50 \mathrm{mg} / \mathrm{kg})$ and the testes were aseptically removed and perfused with l-2 ml ice-cold collagenase ( $1 \mathrm{mg} / \mathrm{ml}$ ) in isolation medium (M-199 buffered with $0.71 \mathrm{~g} \mathrm{NaHCO}_{3} / \mathrm{l}$ and $2.21 \mathrm{~g} \mathrm{Hepes} / 1$ supplemented with $0.1 \% \mathrm{BSA}$, and $25 \mathrm{mg} \mathrm{STI} / 1, \mathrm{pH} 7.4$ ) using a 27 -gauge needle. The testes were then decapsulated and placed in a $250 \mathrm{ml}$ tissue culture flask containing $20 \mathrm{ml}$ isolation medium. Testes from 16- and 19-day-old rats were decapsulated without perfusion. Then, $20 \mathrm{ml}$ of collagenase in isolation medium $(0.5 \mathrm{mg} / \mathrm{ml})$ were added to the flask containing the decapsulated testes and the testes were dissociated while shaking at $80 \mathrm{cycles} / \mathrm{min}$ at $34^{\circ} \mathrm{C}$. After $10 \mathrm{~min}, 160 \mathrm{ml}$ isolation medium were added to each flask and the seminiferous tubules allowed to settle for $3 \mathrm{~min}$ at unit gravity. Subsequently, the cell suspension was filtered through a double nylon mesh of $20 \mu \mathrm{m}$ gauge into four $50-\mathrm{ml}$ centrifuge tubes. The filtrates were sedimented by centrifugation at $150 \mathrm{~g}$ for $10 \mathrm{~min}$ at room temperature to harvest the cells. Cells obtained from 8 dissociated testes were suspended in $14 \mathrm{ml}$ suspension medium $\left(1 \times \mathrm{Ca}^{2+}\right.$, $\mathrm{Mg}^{2+}$-free HBSS buffered with $0.35 \mathrm{~g}$ sodium bicarbonate $/ 1$ and containing $0.25 \% \mathrm{BSA}$ and $25 \mathrm{mg} \mathrm{STI} / \mathrm{l}, \mathrm{pH} 7 \cdot 4$ ). The suspension was thoroughly mixed with $21 \mathrm{ml}$ iso-osmotic Percoll made by a dilution of $11: 1(\mathrm{v} / \mathrm{v})$ of Percoll with $10 \times$ concentrated $\mathrm{Ca}^{2+}, \mathrm{Mg}^{2+}$-free HBSS, then centrifuged in a fixed angle rotor (JA-20, Beckman) at $20000 \mathrm{~g}$ for 60 min at $4^{\circ} \mathrm{C}$. After centrifugation, a continuous, linear density gradient was generated in which the cells became partitioned according to their densities. Layers of Percoll from densities of $1.000-1.060 \mathrm{~g} / 1$ (fraction A), $1.061-$ $1.074 \mathrm{~g} / \mathrm{l}$ (fraction B), $1.075-1.090 \mathrm{~g} / \mathrm{l}$ (fraction C), and $>1.090 \mathrm{~g} / \mathrm{l}$ (fraction D) were separated using disposable serological pipettes. The fractions were then diluted with suspension medium in a $50-\mathrm{ml}$ centrifuge tube and centrifuged at $150 \mathrm{~g}$ for $10 \mathrm{~min}$ at room temperature. Cells obtained from each fraction were resuspended in Ham's F12/DME 
$(l: I, v / v)$ culture media and counted with a haemocytometer. The viability of the cells was determined by simultaneous staining with fluorescein diacetate-propidium iodide (Jones \& Senft, 1985) before processing for histochemical, morphological and functional characterization.

\section{Characterization of purified Leydig cells}

Histochemical analysis of isolated cells. The percentage of Leydig cells in each fraction was histochemically determined by staining for $3 \beta$-hydroxysteroid dehydrogenase ( $3 \beta$-HSD) as previously described by Klinefelter et al. (1987). The cells were stained at $32^{\circ} \mathrm{C}$ in a humidified incubator of $95 \%$ air and $5 \% \mathrm{CO}_{2}$ and examined at $\times 630$ with a Zeiss microscope.

Morphological techniques. Immediately after isolation, $3 \times 10^{5}$ cells from each fraction were fixed for $1.5 \mathrm{~h}$ in $2.5 \%$ glutaraldehyde in $0.2 \mathrm{M}$-collidine buffer at 4 C. Following a wash with $0.2 \mathrm{M}$-collidine buffer, the cells were postfixed in $1 \% \mathrm{OsO}_{4}\left(2 \% \mathrm{OsO}_{4}\right.$ reduced with $3 \%$ potassium ferrocyanide, $\left.1: 1, \mathrm{v} / \mathrm{v}\right)$ for $1 \mathrm{~h}$ at room temperature. The cells were washed twice with cold $\left(4^{\circ} \mathrm{C}\right)$ phosphate-buffered saline (PBS) and dehydrated in a graded series of alcohols, cleared in propylene oxide, and embedded in Epon-araldite. Thick sections $(1 \mu \mathrm{m})$ for light microscopy were cut using an LKB NOVA ultramicrotome. The sections were stained with toluidine blue and examined with a Zeiss microscope. For transmission electron microscopy, silver-gold sections were also cut from the same blocks, stained with uranyl acetate and lead citrate, and viewed with a JEOL 100 S electron microscope.

Functional characterization of isolated cells. Immediately after isolation, $3 \times 10^{4}$ cells from each fraction were incubated in $0.5 \mathrm{ml} \mathrm{Ham}$ 's F12/DME $(1: 1, \mathrm{v} / \mathrm{v})$ medium supplemented with ITS ${ }^{+}$, with and without maximally stimulating concentrations of hCG (500 mi.u./well). Incubations were carried out in 24-well culture plates (Nunclon Delta, Thomas Scientific, Swedesboro, NJ, USA; surface area $2 \mathrm{~cm}^{2}$ per well) in an humidified incubator of $95 \%$ air and $5 \%$ $\mathrm{CO}_{2}$, maintained at $32^{\circ} \mathrm{C}$. We did not find any difference in the testosterone production by Leydig cells incubated at $32^{\circ} \mathrm{C}$, $33^{\circ} \mathrm{C}$ and $34^{\circ} \mathrm{C}$. After $20 \mathrm{~h}$, medium from each well was collected, centrifuged $\left(180 \mathrm{~g}, 10 \mathrm{~min} 4^{\circ} \mathrm{C}\right)$ and the supernatant assayed for testosterone by radioimmunoassay (RIA) using the procedure provided by ICN Immunobiologicals (Lisle, IL, USA).

\section{Isolation and culture of Sertoli, epididymal, peritubular and prostatic cells}

Sertoli cells were isolated from 19-day-old Sprague-Dawley rats and cultured in Dulbecco's modified Eagle's medium (DMEM) supplemented with ovine FSH, insulin, transferrin, oestradiol-17 $\beta$, selenium, mEGF and testosterone (serum-free defined medium, SFDM) as we reported previously (Hadley et al., 1985). At the time of plating, Sertoli cells were mostly in the form of single cells although a few aggregates of 5-10 Sertoli cells were present and contained a contamination of $<10 \%$ germ cells (up to pachytene spermatocytes), $1 \%$ peritubular cells, and $<1 \%$ Leydig and fibroblastic cells, as defined by electron microscopy (data not shown). The cells were plated on reconstituted basement membrane extracts, 'Matrigel' (Collaborative Research Inc; Lexington, MA, USA)-coated Millipore filters $\left(0.45 \mu \mathrm{m}\right.$ pore size with an effective membrane area of $4.2 \mathrm{~cm}^{2}$ ) in bicameral (Millicell-HA) chambers (Millipore Corp, Bedford, MA, USA) at a density of $2.5 \times 10^{6}$ cells/chamber. The Matrigel was diluted 1:8 with sterile doubledistilled water before use. The cell cultures were maintained at $34^{\circ} \mathrm{C}$ in an humidified incubator in an atmosphere of $95 \%$ air and $5 \% \mathrm{CO}_{2}$. After $24 \mathrm{~h}$, media from all chambers were removed and discarded. Subsequently, culture media were changed every 2 days and the cultures were maintained for a maximum of 12 days. Sertoli cell-conditioned media obtained from the same set of cultures from the 2 nd to the last day of culture were pooled and used for individual studies. Epididymal epithelial cells, prostatic adenocarcinoma cells, and rat peritubular myoid cells were isolated and cultured as described previously by Byers et al. (1986), Chang \& Pollard (1977) and Skinner \& Fritz (1985), respectively. Pooled spent media from these cultures were centrifuged to remove debris and then processed for protein content.

\section{Preparation of cell-secreted proteins}

Spent media obtained from the above cell cultures were dialysed and concentrated at $4^{\circ} \mathrm{C}$ (to prevent degradation of the secreted proteins) using Amicon YMT centriprep-10 ultrafilter membranes (cut off point 10000 molecular weight). Samples were sterilized by filtration through $0.20 \mu \mathrm{m}$ pore Millex-GV filters (Millipore) and the protein concentration determined according to the method of Bradford (Bradford, 1976), using BSA as a standard. Testicular interstitial fluid was obtained from normal adult rat testes according to the method of Turner et al. (1984), dialysed using Amicon YMT centriprep-10 filter membranes to remove steroids and low molecular weight $\left(M_{\mathrm{r}}<10000\right)$ proteins, and processed for protein content as described above. Blood was obtained from phenobarbitone-anaesthetized adult male Sprague-Dawley rats by intracardiac puncture. The blood was allowed to clot at $4^{\circ} \mathrm{C}$ for $3 \mathrm{~h}$ and centrifuged at $180 \mathrm{~g}$ for $30 \mathrm{~min}$ at $4^{\circ} \mathrm{C}$. Serum obtained was dialysed using Amicon YMT centriprep-10 filter membranes before protein concentration was determined. 


\section{Heat and trypsin treatment of Sertoli cell-secreted proteins (SCSP), epididymal cell-secreted protein (EpCSP), testicular interstitial fluid (TIF), and adult rat serum proteins}

The heat sensitivity of the biologically active components of SCSP, EpCSP, TIF, and rat serum was tested by immersing a sample of each in a boiling water bath for $4 \mathrm{~h}$ (some samples of the SCSP were also heated for 5,15 and $30 \mathrm{~min}$ ). The sensitivity to protease was examined by incubating separate aliquants of these samples with $5 \%$ trypsin for $8 \mathrm{~h}$ at $37^{\circ} \mathrm{C}$ followed by $10 \% \mathrm{STI}$ ( $1 \mathrm{mg} \mathrm{STI}$ inhibits $2.3 \mathrm{mg}$ trypsin) neutralization for $1 \mathrm{~h}$ at the same temperature. After these treatments, the samples were tested for their ability to stimulate Leydig cell testosterone secretion and $\left[{ }^{3} \mathrm{H}\right]$ thymidine incorporation in vitro.

\section{Heparin-agarose and concanavalin A-Sepharose 4B chromatography of SCSP}

Concentrated Sertoli cell-secreted proteins $(1 \mathrm{mg} / \mathrm{ml})$ were placed in dialysis tubing with an exclusion limit of $M_{\mathrm{r}}$ 3500 (Thomas Scientific, Philadelphia, PA, USA) and dialysed against buffer A ( $10 \mathrm{~mm}-\mathrm{KH}_{2} \mathrm{PO}_{4}+0.15 \mathrm{M}-\mathrm{NaC}(\mathrm{pH}$ $7.4)$ at $4^{\circ} \mathrm{C}$ for $4 \mathrm{~h}$. The dialysate was divided into two parts. One-half was applied to a $2.5 \mathrm{ml}$ column of Affi-Gel heparin (heparin-agarose) that had earlier been equilibrated with buffer A. Bound proteins were eluted with $2.0 \mathrm{M}$ $\mathrm{NaCl}$ in buffer $\mathrm{A}$. The other half of the dialysate was applied to a $2.7 \mathrm{ml}$ column of concanavalin A-Sepharose equilibrated with buffer $\mathrm{A}$ at $4^{\circ} \mathrm{C}$. Proteins bound to con A-Sepharose were eluted with $0.5 \mathrm{M} \alpha$-D-methylglucoside in buffer $A$. Bound and unbound proteins from both columns were concentrated with Amicon YMT centriprep-10 filter membranes and the buffer was exchanged against double-distilled water. Protein concentration was determined as described above. Subsequently, each fraction was tested for its ability to stimulate $\left[{ }^{3} \mathrm{H}\right]$ thymidine incorporation into Leydig cells in vitro.

\section{$\left[{ }^{3} \mathbf{H} \mid\right.$ Thymidine incorporation assay}

The ability of SCSP to stimulate Leydig cell DNA synthesis in vitro was examined by incorporation of $\left[{ }^{3} \mathrm{H}\right]$ thymidine into cold $5 \%$ trichloroacetic acid (TCA)-precipitable and I $\mathrm{N}$-sodium hydroxide $(\mathrm{NaOH}$ )-soluble DNA of the cells. Immediately after isolation, $3 \times 10^{4}$ cells were plated in 24-well dishes containing DMEM supplemented with $0.1 \%$ BSA and treated with various concentrations (ranging from 0.1 to $72.0 \mu \mathrm{g} /$ well in $20-80 \mu$ l fluid volumes) of SCSP in a final incubation volume of $0.5 \mathrm{ml}$. After the addition of $3 \mu \mathrm{Ci}\left[{ }^{3} \mathrm{H}\right]$ thymidine, the cells were incubated at $32{ }^{\circ} \mathrm{C}$ in an humidified incubator of $95 \%$ air and $5 \% \mathrm{CO}_{2}$ for $5 \mathrm{~h}$. We did not find any difference in $\left[{ }^{3} \mathrm{H}\right]$ thymidine incorporation by Leydig cells incubated at $32^{\circ} \mathrm{C}, 33^{\circ} \mathrm{C}$, and $34^{\circ} \mathrm{C}$. At the end of the incubation period, the radioactive medium was removed and discarded. Cells were then washed with ice-cold phosphate-buffered saline (PBS) followed by $1 \mathrm{ml}$ ice-cold $10 \%$ TCA for $10 \mathrm{~min}$. After two additional washes with TCA, $5 \mathrm{~min}$ each, the cells were rinsed three times with ice-cold absolute ethanol and air dried. Subsequently, $0.5 \mathrm{ml}$ of freshly prepared $1 \mathrm{~N}-\mathrm{NaOH}$ was added to the cells and incubated at $37^{\circ} \mathrm{C}$ for $30 \mathrm{~min}$. Then, $0.2 \mathrm{ml}$ of the $\mathrm{NaOH}$ solution was collected, cooled, and counted in $10 \mathrm{ml}$ of acidified scintillation fluid with a Beckman LS 8100 beta counter with a counting efficiency of about $60 \%$. To explore the specificity of the SCSP effect on Leydig cell $\left[{ }^{3} \mathrm{H}\right]$ thymidine incorporation, we examined the effect(s) of proteins secreted by various other cells on Leydig cell $\left[{ }^{3} \mathrm{H}\right]$ thymidine incorporation in vitro. These proteins included peritubular cell-secreted proteins (PeCSP), prostatic cell-secreted proteins (PrCSP), epididymal cell-secreted proteins (EpCSP) (both normal and heat treated), dialysed adult male rat serum (both normal and heat treated), serum-free defined medium (SFDM), testicular interstitial fluid (TIF) (both normal and heat treated), SCSP obtained from Sertoli cells cultured in the absence of FSH and/or testosterone), and proteins produced by Sertoli cells cultured on plastic without Matrigel. The concentration of the various proteins used was approximately $9 \cdot 0 \mu \mathrm{g} / \mathrm{well}$ (equivalent to the amount of SCSP that stimulated Leydig cell $\left[{ }^{3} \mathrm{H}\right]$ thymidine incorporation maximally during the preliminary studies). The effect of ovine LH ( $25 \mathrm{ng} /$ well $)$ on Leydig cell $\left[{ }^{3} \mathrm{H}\right]$ thymidine incorporation was also studied to exclude the possibility of LH contamination of the SCSP.

\section{Effect of SCSP on adult rat Leydig cell testosterone secretion in vitro}

To investigate testosterone production by the Leydig cells in response to Sertoli cell-secreted proteins (SCSP), $3 \times 10^{4}$ cells from fraction C were incubated with $9.0 \mu \mathrm{g} \mathrm{SCSP}$ in 24-well dishes containing $0.5 \mathrm{ml}$ Ham's F12/DME supplemented with ITS ${ }^{+}$. After $20 \mathrm{~h}$, conditioned media were centrifuged at $180 \mathrm{~g}$ for $10 \mathrm{~min}$ at $4^{\circ} \mathrm{C}$. The supernatants were assayed for testosterone concentration as described above.

\section{Statistical analysis}

Each treatment was examined in triplicate and every observation was repeated at least twice to confirm the reproducibility of the results. Differences between unstimulated and hCG-stimulated testosterone production by isolated $3 \beta$-HSD positive cells in each fraction or between control and SCSP-treated Leydig cells (Fraction C), and differences in $\left[{ }^{3} \mathrm{H}\right]$ thymidine incorporation between control and SCSP-treated Leydig cells was determined by Student's $t$ test (Snedecor \& Cochran, 1980). Differences in testosterone secretion by 3 $\beta$-HSD positive cells in various Percoll density-gradient fractions were determined by analysis of variance with Duncan's multiple range test (Duncan, 1975). 


\section{Results}

\section{Characteristics of isolated cells}

When the crude suspension of rat testicular cells was centrifuged in a $60 \%$ continuous, linear, Percoll-density gradient, 6 visible bands were obtained. These were separated into 4 fractions (designated A-D). Fraction A was the least dense and Fraction D the most dense. Fraction A (upper $10 \mathrm{ml}$; density, $1.000-1.060 \mathrm{~g} / \mathrm{ml}$ ) contained $95 \%$ of the total isolated cell number. These consisted of a heterogeneous cell population that included macrophages (in cells obtained from mature rats), connective tissue cells (fibroblasts, endothelial cells, pericytes), lymphocytes, germ cells, Leydig cells, and damaged cells as shown by light and electron microscopy and the cell viability test. Approximately $10 \%$ of the cells in this fraction were $3 \beta$-HSD positive. These represented $71 \cdot 2 \%$ of the total isolated $3 \beta$-HSD-positive cells. In Fraction B (density $1.061-1.074 \mathrm{~g} / \mathrm{ml}$ ), $60-90 \%$ of the cells stained positively for $3 \beta$-HSD. Most of the morphologically identifiable Leydig cells in this fraction were immature (small or intermediate in size, polygonal, and epithelioid cells with Leydig cell nuclei and moderate to dense granular cytoplasm; Fig. 1a). Residual bodies and spermatozoa were also present in this fraction. Fraction C (density $1.075-1.090 \mathrm{~g} / \mathrm{ml}$ ) contained $>96 \%$ of Leydig cells at all ages as determined by morphology (Figs $1 b, 1 c$ ) and $3 \beta-H S D$ staining (Fig. 2). Most of the Leydig cells in this fraction were morphologically mature (large, polygonal and epithelioid with typical Leydig cell nuclei and dense granular cytoplasm). The predominance of mature Leydig cells in this fraction is shown by the light micrograph in Fig. 1(b). At the electron microscopic level (Fig. 1c), the cells displayed intact plasma membranes with short cytoplasmic processes, abundant smooth endoplasmic reticulum, numerous mitochondria with lamellar cristae, scattered rough endoplasmic reticulum, lipid droplets, round nuclei with one or more nucleoli, and prominent rims of heterochromatin. Comparison of the morphology of Percoll density gradient Fraction C Leydig cells obtained from rats of ages 16-90 days revealed that the proportion of morphologically mature Leydig cells increased with the age of the rats from which they were isolated. That is, the percentage of terminally differentiated Leydig cells in this fraction was lowest in the cell preparations isolated from 16-day-old rats and highest in 90-day-old rats (data not shown). The viability of the cells ranged from 98 to $100 \%$ at the time of isolation and 80 to $95 \%$ after 3 days of incubation. Spermatozoa present in this fraction were removed (at the expense of Leydig cell yield) by centrifugation at $80 \mathrm{~g}$ for $10 \mathrm{~min}$. Fraction D (last $9 \mathrm{ml}$ ) also contained $>96 \%$ viable Leydig cells as shown by the cell viability test, $3 \beta$-HSD staining, and light and electron microscopy. Leydig cells in Fraction $\mathrm{D}$ were contaminated with debris, a few red blood cells, and spermatozoa.

Figure 3 shows testosterone secretion by $3 \beta$-HSD-positive cells from different fractions of the Percoll density gradient. Leydig cells from Fraction $C$ produced $20 \pm 0.03$ and $1.4 \pm 0.04 \mathrm{ng}$ testosterone $/ 10^{4}$ cells when incubated for $20 \mathrm{~h}$ with and without a maximally stimulating dose of hCG, respectively. Although Leydig cells from Fractions $\mathrm{B}$ and $\mathrm{C}$ showed maximum testosterone response (9-14-fold increase) to stimulation by $500 \mathrm{mi}$.u. hCG/well, Leydig cells from Fraction C secreted significantly $(P<0.01)$ greater basal and hCG-stimulated testosterone than did intact Leydig cells from Fraction B. Cells isolated from Fraction D also produced significantly $(P<0.00 \mathrm{l})$ less basal and hCG-stimulated testosterone than did Fraction $\mathrm{C}$ cells (Fig. 3 ) hence the former was excluded from this study. Taken together, these results indicate that Fraction $\mathrm{C}$ contained a pure population of morphologically identifiable and functionally competent Leydig cells and these were used in all subsequent studies.

\section{Effects of SCSP on $\left[{ }^{3} \mathrm{H}\right]$ thymidine incorporation by Leydig cells isolated from 70-day-old rats}

SCSP $\left(M_{\mathrm{r}}>10000\right)$ stimulated a dose-dependent increase in $\left[{ }^{3} \mathrm{H}\right]$ thymidine incorporation by Leydig cells isolated from 70 -day-old rats (Fig. 4). Incubation of purified Leydig cells with as little 

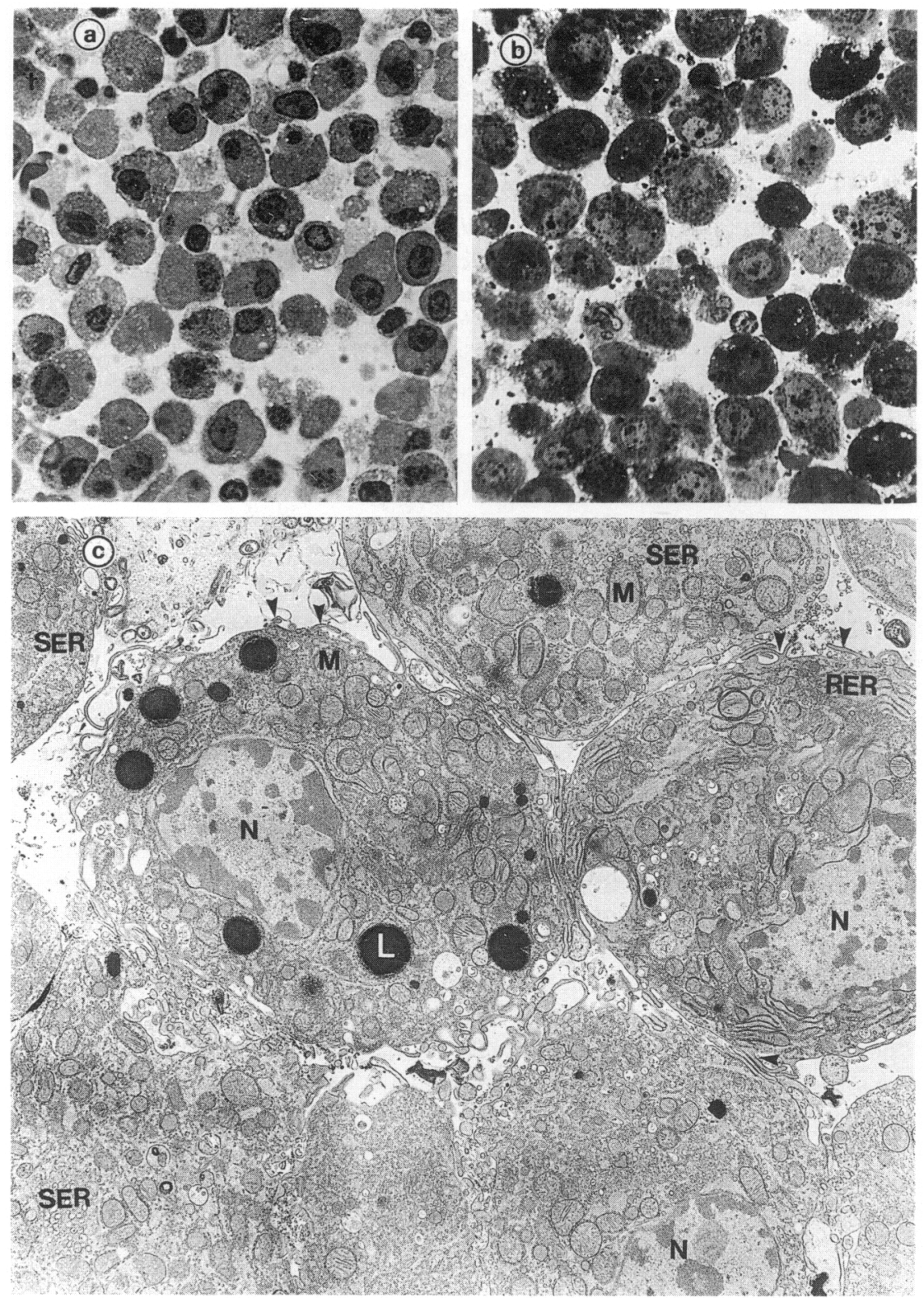

Fig. 1. Light micrographs of 70-day-old rat Leydig cells separated by Percoll density gradients. (a) Fraction B (density, $1.061-1.074 \mathrm{~g} / \mathrm{ml}$ ). No predominant contaminating cell type is seen. Note the presence of many immature Leydig cells (small or intermediate in size, polygonal, and epithelioid cells with typical Leydig cell nuclei and moderate to dense granular cytoplasm). $\times 950$. (b) Fraction C (density, $1.075-1.090 \mathrm{~g} / \mathrm{ml}$ ). No predominant contaminating cell type is seen. Note the large size and dense granular cytoplasm of the cells. $\times 950$. (c) Fraction $C$ (density, 1.075-1.090 g/ml). This micrograph is typical of cells in this fraction. Note the intact membranes of the cells with short cytoplasmic processes (arrowheads), numerous smooth endoplasmic reticulum (SER), mitochondria (M), lipid droplets (L), and rough endoplasmic reticulum (RER). These are common features of Leydig cells in vivo. $\times 6060$ 


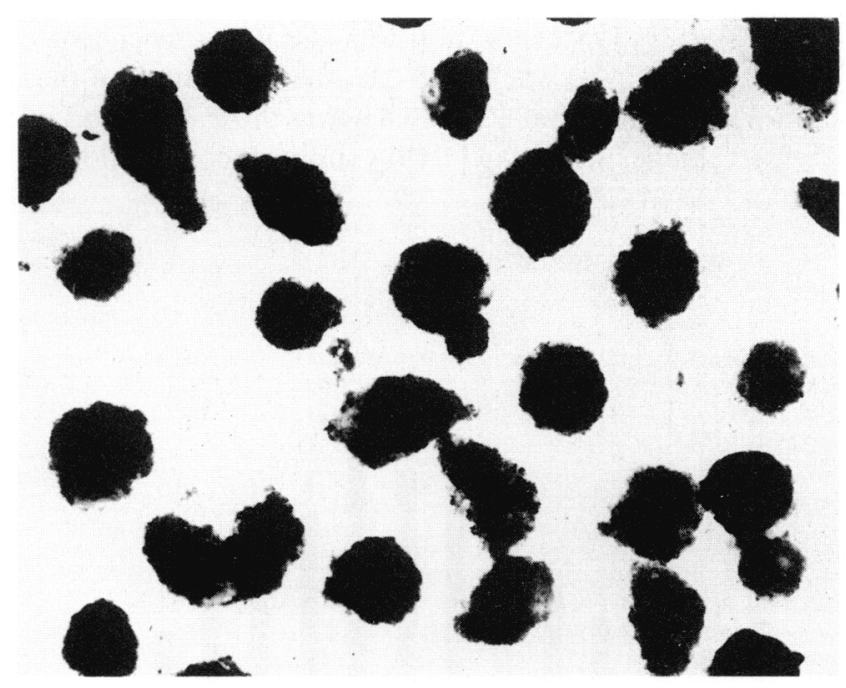

Fig. 2. Light micrograph of $3 \beta$-hydroxysteroid dehydrogenase (3$\beta$-HSD) staining of cells from Percoll density gradient Fraction C (density, 1.075-1.090 g/ml). Staining is uniform among the cells and no predominant contaminating cell type is seen. $\times 480$.

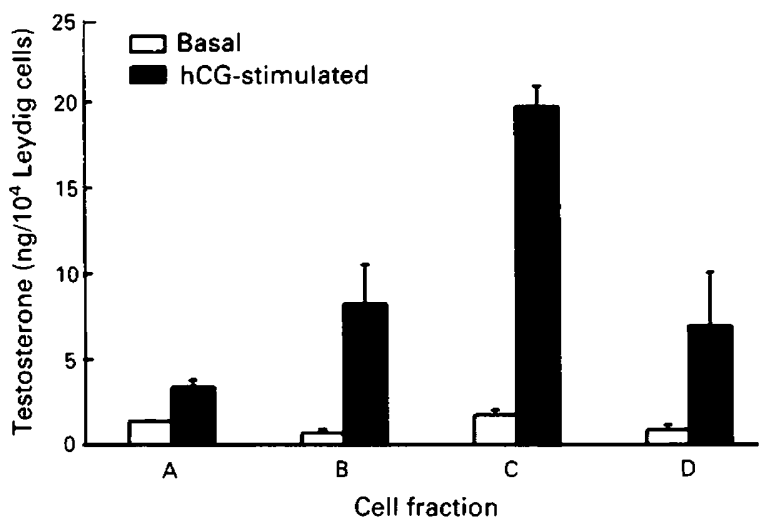

Fig. 3. Testosterone secretion by Leydig cells from 70-day-old rats from different fractions of Percoll density gradient. Values are the mean \pm s.d. of 6 different experiments, each conducted in triplicate $(n=18)$. Cells from Fraction C (density $1.075-1.090 \mathrm{~g} / \mathrm{ml}$ ) secreted significantly $(P<0.01)$ more basal and hCG-stimulated testosterone than did cells from other fractions.

as $0 \cdot 1 \mu \mathrm{g} \mathrm{SCSP} /$ well consistently induced a small but significant increase ( $10 \pm 1 \%$ above control; $P<0.001)$ in tritiated thymidine incorporation. The maximum stimulation $(48 \pm 3 \%$ above control) of $\left[{ }^{3} \mathrm{H}\right]$ thymidine incorporation was obtained with an SCSP dose of $9 \mu \mathrm{g} /$ well. Increasing the dose above $18 \mu \mathrm{g} /$ well did not stimulate this process in these cells. To determine whether the stimulatory component of SCSP acts on replicative DNA synthesis or DNA repair, we examined the effects of hydroxyurea (a specific inhibitor of replicative DNA synthesis; Wawra \& Wintersberger, 1983) on $\left[{ }^{3} \mathrm{H}\right]$ thymidine incorporation by adult rat Leydig cells. Addition of $4 \mathrm{~mm}$-hydroxyurea to the incubation medium significantly $(P<0.001)$ decreased the basal $\left[{ }^{3} \mathrm{H}\right]$ thymidine incorporation from $105 \pm 2$ to $42 \pm 7$ c.p.m. $/ 10^{4}$ Leydig cells and the SCSP-stimulated value from $156 \pm 3$ to $94 \pm 2$ c.p.m. $/ 10^{4}$ Leydig cells without affecting the viability of the cells. The stimulatory effect of 
SCSP on Leydig cell $\left[{ }^{3} \mathrm{H}\right]$ thymidine incorporation was also time-dependent (data not shown). A significant stimulatory effect $(P<0.01)$ was found $2 \mathrm{~h}$ after incubation of the cells with SCSP and the maximal stimulation was reached after $12 \mathrm{~h}$. Extending the time period of SCSP exposure did not further enhance the percentage increase in $\left[{ }^{3} \mathrm{H}\right]$ thymidine incorporation.

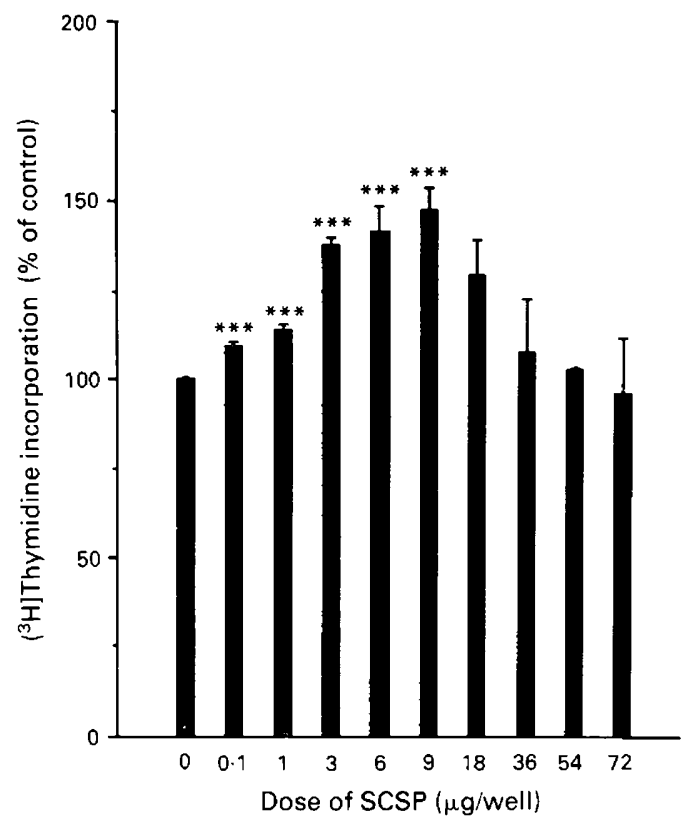

Fig. 4. Effects of Sertoli cell-secreted proteins (SCSP) on $\left[{ }^{3} \mathrm{H}\right]$ thymidine incorporation by purified Leydig cells isolated from 70-day-old rats. SCSP was obtained from immature rat Sertoli cells cultured in SFDM. $\left[{ }^{3} \mathrm{H}\right]$ thymidine incorporation by Leydig cells incubated in culture medium alone (control value) representing $100 \%$ was $105 \pm 2$ c.p.m. $/ 10^{4}$ Leydig cells. Counts of radioactivity in wells containing culture medium and radioactive thymidine without cells or cells without radioactive thymidine were negligible. Each point is the mean \pm s.d. of 4 separate experiments, each conducted in triplicate. ${ }^{* * *} P<0 \cdot 001$, compared to the control value.

Effects of PrCSP, PeCSP, rat serum, testicular interstitial fluid proteins, EpCSP, oLH EGF and SFDM on $\left.\right|^{3} \mathrm{H} \mid$ thymidine incorporation by Leydig cells isolated from 70-day-old rats in vitro

Prostatic cell-secreted proteins, peritubular cell-secreted proteins, testicular interstitial fluid (normal and heat-treated), adult male rat serum proteins (normal and heat-treated), serum-free defined medium, and ovine $\mathrm{LH}$ at $25 \mathrm{ng} /$ well (a dose which stimulated a 10-fold increase in Leydig cell testosterone secretion from a basal level of $1 \cdot 7 \pm 0 \cdot 14$ to $18 \cdot 3 \pm 1 \cdot 2 \mathrm{ng} / 10^{4}$ Leydig cells) had no significant stimulatory effect on $\left[{ }^{3} \mathrm{H}\right]$ thymidine incorporation by Leydig cells isolated from 70 -dayold rats in vitro (Table 1). However, higher doses of testicular interstitial fluid $(480 \mu \mathrm{g} / \mathrm{well})$ and adult rat serum proteins $(430 \mu \mathrm{g} / \mathrm{well}$ ) (approximate concentrations of the proteins to which Leydig cells are exposed in vivo), and normal epididymal cell-secreted proteins $(9 \cdot 0 \mu \mathrm{g} / \mathrm{well})$ significantly $(P<0.001)$ stimulated rat Leydig cell $\left[{ }^{3} \mathrm{H}\right]$ thymidine incorporation (Table 1$)$. Since Sertoli cells produce an epidermal growth factor (EGF)-like substance (Bellve \& Zheng, 1989) and mEGF stimulates cell proliferation in mass cultures of Leydig tumour cells (Ascoli, 1981), we also examined the effect of EGF on Leydig cell $\left[{ }^{3} \mathrm{H}\right]$ thymidine incorporation. As shown in Table 1, this 
Table 1. Effects of PrCSP, PeCSP, adult rat serum, TIF proteins, EpCSP, oLH, EGF, and SFDM on $\left[{ }^{3} \mathrm{H}\right]$ thymidine incorporation by 70 day-old rat Leydig cells in vitro

\begin{tabular}{|c|c|}
\hline Test proteins/medium & $\%$ Of control \\
\hline Culture medium (control) & $100 \pm 1$ \\
\hline $\begin{array}{l}\text { Prostatic cell-secreted } \\
\text { proteins }\end{array}$ & $100 \pm 12$ \\
\hline $\begin{array}{l}\text { Peritubular cell-secreted } \\
\text { proteins }\end{array}$ & $77 \pm 16$ \\
\hline $\begin{array}{l}\text { Adult male rat serum } \\
\text { proteins }\end{array}$ & $101 \pm 4\left(133 \pm 1^{* *}\right) \dagger$ \\
\hline $\begin{array}{l}\text { Heat-treated adult male } \\
\text { rat serum proteins }\end{array}$ & $100 \pm 7$ \\
\hline $\begin{array}{l}\text { Testicular interstitial fluid } \\
\text { Heat-treated testicular }\end{array}$ & $84 \pm 6\left(143 \pm 13^{* *}\right)_{+}^{+}$ \\
\hline $\begin{array}{l}\text { interstitial fluid } \\
\text { Epididymal cell-secreted }\end{array}$ & $86+1 * *$ \\
\hline proteins & $991 \pm 23^{* * *}$ \\
\hline $\begin{array}{l}\text { Heat-treated epididymal } \\
\text { cell-secreted proteins }\end{array}$ & $100 \pm 5$ \\
\hline Ovine luteinizing & \\
\hline hormone & $116 \pm 29$ \\
\hline $\begin{array}{l}\text { Epidermal growth factor } \\
\text { (EGF) }\end{array}$ & ${ }^{a} 59 \pm 5^{* *} ;{ }^{b} 59 \pm 5^{* *}$ \\
\hline $\begin{array}{l}\text { Serum-free defined } \\
\text { medium }\end{array}$ & $100 \pm 2$ \\
\hline
\end{tabular}

Immediately after isolation, $3 \times 10^{4} 3 \beta$-HSD-positive cells were incubated with $\sim 9.0 \mu \mathrm{g} /$ well of the test proteins. The doses of EGF tested were (a) 5.0 and (b) $10.0 \mathrm{ng} /$ well, while the dose of oLH used was $25 \mathrm{ng} /$ well. Values are the mean \pm s.d. of triplicate wells.

†Value obtained with $430 \mu \mathrm{g}$ normal adult male rat serum proteins/well.

‡Value obtained with $480 \mu \mathrm{g}$ normal testicular interstitial fluid/well.

${ }^{* *} P<0.01 ;{ }^{* * *} P<0.001 ;$ compared to control value.

factor at concentrations of 5 and $10 \mathrm{ng} /$ well did not stimulate adult rat Leydig cell $\left[{ }^{3} \mathrm{H}\right]$ thymidine incorporation; in fact, it significantly $(P<0.01)$ inhibited this process in these cells.

\section{Partial characterization and hormonal regulation of Sertoli cell-secreted factor(s) which stimulates $\left[{ }^{3} \mathrm{H} \mid\right.$ thymidine incorporation in 70-day-old rat Leydig cells in vitro}

Table 2 demonstrates the physicochemical characteristics of the component(s) of the crude SCSP which stimulated $\left[{ }^{3} \mathrm{H}\right]$ thymidine incorporation in 70 -day-old rat Leydig cells. The factor(s) was trypsin-sensitive, heat-stable, and bound to a heparin-agarose affinity column but not to a concanavalin A-Sepharose 4B affinity column. Proteins obtained from Sertoli cells cultured in SFDM without either testosterone or FSH also induced a significant increase $(P<0.001)$ in rat Leydig cell $\left[{ }^{3} \mathrm{H}\right]$ thymidine incorporation, but proteins secreted by Sertoli cells cultured in SFDM in which both FSH and testosterone were excluded had no significant stimulatory effect on Leydig cell $\left[{ }^{3} \mathrm{H}\right]$ thymidine incorporation (Table 3). SCSP recovered after ultrafiltration of Sertoli cell-conditioned media using Amicon YMT centriprep-30 filter membranes (cut off point, $M_{\mathrm{r}} 30000$ ) and proteins secreted by Sertoli cells cultured on plastic dishes without Matrigel also induced a significant increase $(P<0.001)$ in 70-day-old rat Leydig cell $\left[{ }^{3} \mathrm{H}\right]$ thymidine incorporation (from the control value of $159 \pm 9$ to $240 \pm 4$ and from $179 \pm 10$ to $262 \pm 5$ c.p.m. $/ 10^{4}$ Leydig cells, respectively; mean \pm s.d., $n=6$ ). 
Table 2. Physicochemical characterization of the Sertoli cell secreted protein(s) which stimulate $\left[{ }^{3} \mathrm{H}\right]$ thymidine incorporation in 70 -day-old rat Leydig cells in vitro

\begin{tabular}{lc}
\hline & $\begin{array}{c}{\left[{ }^{3} \mathrm{H}\right] \text { thymidine }} \\
\text { incorporation } \\
\text { (c.p.m. } / 10^{4} \\
\text { Leydig cells } / 5 \mathrm{~h} \text { ) }\end{array}$ \\
Nature of SCSP & $105 \pm 2$ \\
Culture medium (no SCSP) & $82 \pm 7^{* *}$ \\
Trypsin-treated SCSP & $135 \pm 8^{* *}$ \\
Heat-treated SCSP & $107 \pm 4$ \\
Concanavalin A-bound SCSP & $150 \pm 6^{* * *}$ \\
Heparin-bound SCSP & \\
\hline Immediately after isolation, $3 \times 10^{4} \quad 3 \beta-\mathrm{HSD}$-positive \\
cells were incubated with $9 \cdot 0 \mu \mathrm{g}$ SCSP/well after the \\
designated treatment. SCSP samples were heat-treated \\
$\left(100^{\circ} \mathrm{C}\right.$ ) for 5,15 and 30 min and $4 \mathrm{~h}$. Values are \\
the mean \pm s.d. of triplicate wells. $* * P<0 \cdot 01 ;$ \\
$* * * P<0.001$, compared to control value.
\end{tabular}

Table 3. Effects of proteins secreted by Sertoli cells cultured in SFDM without testosterone and/ or FSH on $\left[{ }^{3} \mathrm{H}\right]$ thymidine incorporation by 70 day-old rat Leydig cells in vitro

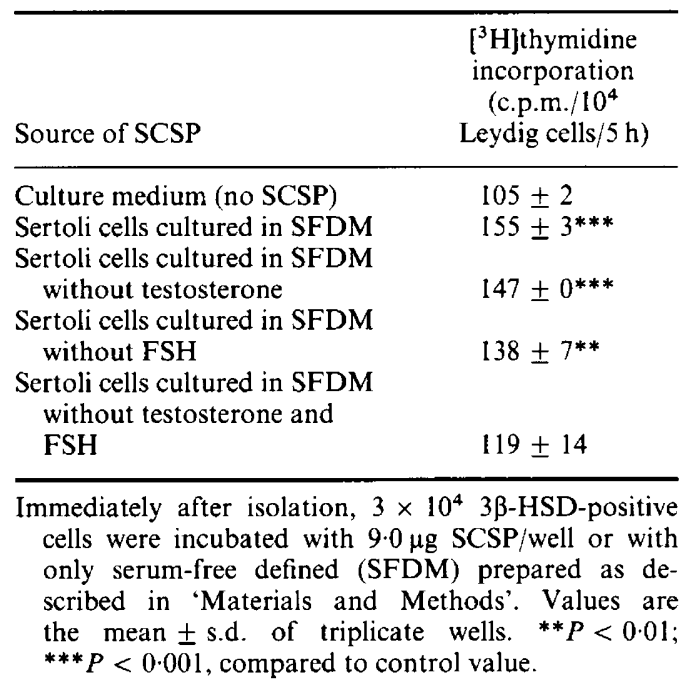

\section{Effects of various SCSP preparations on testosterone secretion by 70-day-old rat Leydig cells in vitro}

There have been many reports demonstrating that Sertoli cells secrete a proteinaceous substance(s) which stimulates adult rat Leydig cell steroidogenesis in vitro (Verhoeven \& Cailleau, 1985; Papadopoulos et al., 1987; Perrard-Sapori et al., 1987; Ojeifo et al., 1988). To determine whether the actions of SCSP on rat Leydig cell $\left[{ }^{3} \mathrm{H}\right]$ thymidine incorporation and testosterone secretion are mediated by the same or different protein(s), we examined the effects of various SCSP preparations used in the study of $\left[{ }^{3} \mathrm{H}\right]$ thymidine incorporation by 70 -day-old rat Leydig cells on 
testosterone secretion by the same population of Leydig cells. As expected, a trypsin-sensitive but heat-stable component(s) of SCSP stimulated rat Leydig cell testosterone secretion in a dose- and time-dependent fashion (data not shown). Exclusion of testosterone and/or FSH from the SFDM used in the culture of Sertoli cells did not affect the steroidogenic potency of the Sertoli cell-secreted protein(s) (Table 4).

Table 4. Effects of proteins secreted by Sertoli cells cultured in SFDM without testosterone and/ or FSH on testosterone secretion by 70-day-old rat Leydig cells in vitro

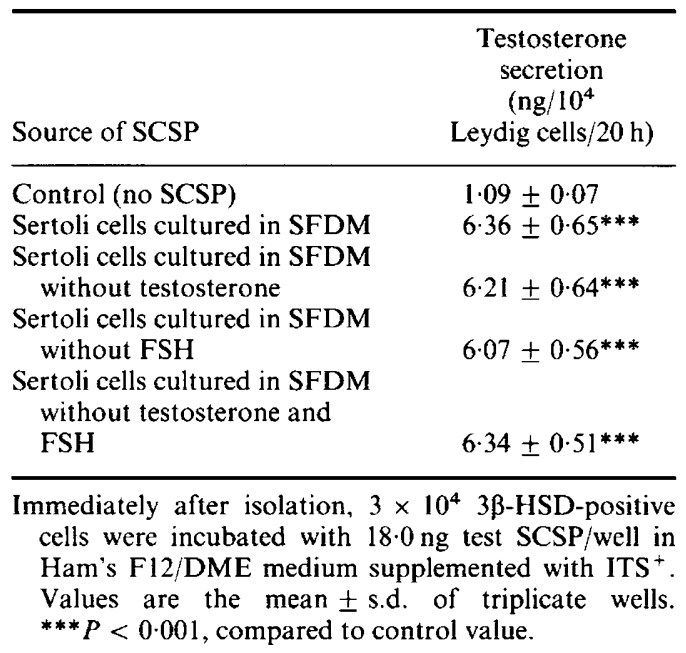

Age dependence of the stimulatory effects of SCSP on rat Leydig cell $\left[{ }^{3} \mathrm{H}\right]$ thymidine incorporation in vitro

Leydig cells prepared from 70-day-old rats are largely mature differentiated cells (see above). As it is possible that the relatively small $(48 \%)$ stimulatory effect of SCSP on $\left[{ }^{3} \mathrm{H}\right]$ thymidine incorporation by 70 -day-old rat Leydig cells is due to the high proportion of terminally differentiated cells in these preparations, we investigated both basal and SCSP-stimulated $\left[{ }^{3} \mathrm{H}\right]$ thymidine incorporation by Leydig cells isolated from rats aged 16-90 days.

As shown in Table 5, basal $\left[{ }^{3} \mathrm{H}\right]$ thymidine incorporation in Leydig cells increased markedly with age from 16 to 26 days and then fell dramatically in Leydig cells isolated from $36,45,70$ and 90-day-old rats. The dose-response effect of SCSP on $\left[{ }^{3} \mathrm{H}\right]$ thymidine incorporation by Leydig cells isolated from rats aged 16, 19,26, 45 and 90 days was similar to that obtained in cells from 70-dayold rats (data not shown). However, a striking age-related difference was noted in the magnitude of the response of the cells to the stimulatory effect of SCSP. In contrast to the relatively small ( $48 \%$ above control value) increase induced by the maximal stimulatory dose $(9 \mu \mathrm{g} /$ well $)$ in 70 -day-old rat Leydig cells, this dose stimulated a $230 \%$ increase in $\left[{ }^{3} \mathrm{H}\right]$ thymidine incorporation by Leydig cells isolated from 26-day-old rats (Table 5). These ages of peak (26 days) and nadir ( 70 days) values of SCSP-stimulation of Leydig cell $\left[{ }^{3} \mathrm{H}\right]$ thymidine incorporation coincide exactly with the ages of maximum and minimum basal $\left[{ }^{3} \mathrm{H}\right]$ thymidine incorporation, respectively (Table 5). They also coincide very closely with the periods of maximum and minimum post-natal increase in Leydig cell number in rat testes in vivo (Knorr et al., 1970; Hardy et al., 1989). 
Table 5. Basal and SCSP-stimulated $\left[{ }^{3} \mathrm{H}\right]$ thymidine incorporation by purified Leydig cells isolated from rats aged $16-90$ days

\begin{tabular}{lcc}
\hline & \multicolumn{2}{c}{$\begin{array}{l}{\left[{ }^{3} \mathrm{H}\right] \text { thymidine incorporation }} \\
\text { (c.p.m./104 }\end{array}$} \\
\cline { 2 - 3 } $\begin{array}{l}\text { Age of rats } \\
\text { (days) }\end{array}$ & Basal & SCSP-stimulated \\
\hline 16 & $543 \pm 6$ & $707 \pm 63$ \\
19 & $781 \pm 86$ & $1594 \pm 24$ \\
26 & $1201 \pm 63$ & $3987 \pm 402$ \\
36 & $132 \pm 15$ & $\mathrm{ND}$ \\
45 & $113 \pm 5$ & $\mathrm{ND}$ \\
70 & $105 \pm 2$ & $155 \pm 3$ \\
90 & $105 \pm 9$ & $113 \pm 11$ \\
\hline
\end{tabular}

Immediately after isolation, $3 \times 10^{4} 3 \beta$-HSD-positive cells were incubated without (basal) or with $9 \cdot 0 \mu \mathrm{g}$ $\mathrm{SCSP} /$ well. Values are the mean \pm s.d. of triplicate wells in at least 3 separate experiments. ND $=$ not determined.

\section{Effect of SCSP on immature rat Leydig cell proliferation in vitro}

Exposure of Leydig cells isolated from 26-day-old rats to SCSP $\left(M_{\mathrm{r}}>10000\right)$ for $48 \mathrm{~h}$ resulted in a dose-dependent increase in the number of the cells (Fig. 5), indicating that the stimulatory effect of SCSP on Leydig cell DNA synthesis thus results in cell proliferation.

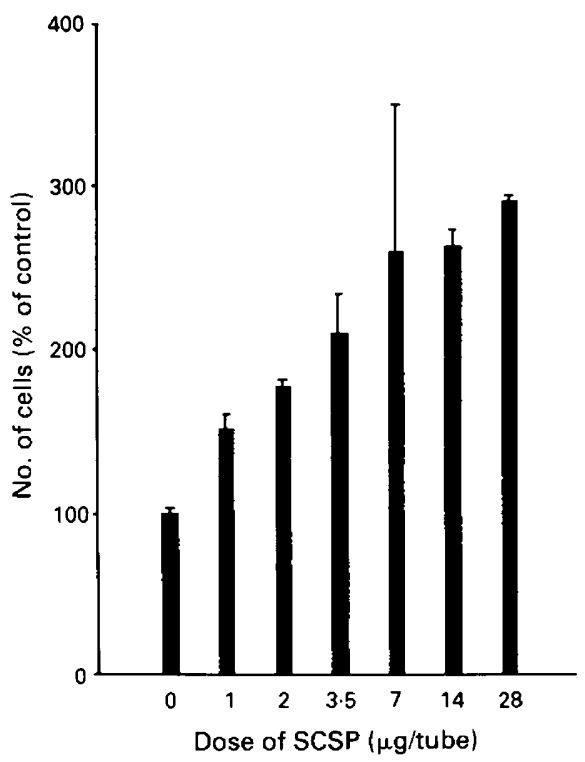

Fig. 5. Dose-response effects of SCSP on 26-day-old rat Leydig cell proliferation in vitro. Immediately after isolation, $3 \times 10^{4} 3 \beta$-HSD-positive cells from Percoll density Fraction $C$ were incubated in $12 \times 75 \mathrm{~mm}$ culture tubes containing $0.5 \mathrm{ml} \mathrm{Ham}$ 's F12/DME with various doses of SCSP (ranging from 0.0 to $28.0 \mu \mathrm{g} /$ tube). After $48 \mathrm{~h}$ of incubation, the tubes were centrifuged at $80 \mathrm{~g}$ for $5 \mathrm{~min}$. Subsequently, $0.45 \mathrm{ml}$ of the incubation medium was gently aspirated from each tube. The cells were then resuspended in the remaining medium and counted with a haemocytometer: $>80 \%$ of these cells stained positive for $3 \beta$-HSD. Values are the mean \pm s.d. of triplicate tubes. 


\section{Discussion}

In adult rats (Teerds et al., 1988), hamsters (Johnson et al., 1987), and bulls (Hooker, 1944), there is a constant replacement of Leydig cells lost by degeneration and dissolution or involutional atrophy. The recruitment of these new cells involves in part, the proliferation of morphologically identifiable Leydig cells (Johnson et al., 1987; Teerds et al., 1988). The attainment of the normal Leydig cell number in rats during the prepubertal and pubertal periods is also generated in part, by the proliferation of morphologically differentiated Leydig cells (Chemes et al., 1976; Hardy et al., 1989). To date, however, the exact factor(s) responsible for this proliferation is not clear. Although several in-vivo studies (Chemes et al., 1976; Christensen \& Peacock, 1980; Abney \& Carswell, 1986; Molenaar et al., 1986; Teerds et al., 1989; Kupio et al., 1989) have demonstrated that $\mathrm{LH} / \mathrm{hCG}$ stimulates Leydig cell DNA synthesis and/or proliferation, they do not discriminate between a direct and indirect action. For instance, it has been reported that injection of large amounts of hCG disrupts spermatogenesis in mature rats (Kerr \& Sharpe, 1989). Since many of the above in-vivo studies involve the administration of prolonged and supraphysiological doses of exogenous hCG, it is uncertain whether the results obtained were due to a direct effect of hCG or to a secondary effect of the hCG-induced disruption of spermatogenesis. The occurrence of Leydig cell hyperplasia in the absence of raised concentrations of plasma LH (Kerr \& Sharpe, 1985; Lauke et al., 1989) suggests that LH/hCG is not the mitogen for these cells and provides strong evidence for the existence of a locally produced Leydig cell mitogen. In fact, neither pure hCG nor LH stimulate $\left[{ }^{3} \mathrm{H}\right]$ thymidine incorporation in rat Leydig cells in vitro (unpublished data).

The results of the present study demonstrate that Sertoli cells secrete a factor(s) which stimulates $\left[{ }^{3} \mathrm{H}\right]$ thymidine incorporation in purified preparations of rat Leydig cells in vitro. This effect is not due to a possible LH contamination of the oFSH or growth factors possibly present in the Matrigel used for the Sertoli cell culture. On the basis of our preliminary characterization, it is tentatively concluded that this factor(s) is a trypsin-sensitive, heat-stable, heparinbinding protein with molecular weight equal to or greater than 30000 . In addition, the inability of this factor to bind concanavalin A suggests that it may not contain mannose residues. The inhibition of SCSP-induced $\left[{ }^{3} \mathrm{H}\right]$ thymidine incorporation in Leydig cells by hydroxyurea (without affecting the viability of the cells) indicates that this factor acts on replicative DNA synthesis and not DNA repair. Based on the reported features of the previously described Sertoli cell-secreted mitogens (see Bellve \& Zheng, 1989, for review) none of the factors appears to have molecular weights, physicochemical characteristics and hormonal regulation that are identical to the factor described in our study, suggesting that the present factor may be different from these other mitogens.

Our observation that high concentrations of adult rat testicular interstitial fluid (an ultrafiltrate of blood) and serum contain a factor(s) which stimulates $\left[{ }^{3} \mathrm{H}\right]$ thymidine incorporation in Leydig cells is compatible with the expected release of Sertoli cell secretory products into serum and/or TIF in order to reach and affect Leydig cells. It is also consistent with the reports that rat testicular interstitial fluid contains a mitogenic factor that could be responsible for the regeneration of Leydig cells in the testes (Risbridger et al., 1987; Drummond et al., 1988). Our failure to detect the presence of this factor(s) in $9.0 \mu \mathrm{g}$ (equivalent amount of SCSP used) of these samples is likely to be due to the presence of large amounts of other proteins in these samples effectively diluting Sertoli cell specific factors. Therefore, additional studies are needed, after purification of the factor(s), to confirm its presence in rat serum and/or TIF. The marked stimulatory effect of EpCSP on Leydig cell $\left[{ }^{3} \mathrm{H}\right]$ thymidine incorporation, although unexpected, is intriguing and is being further investigated. However, the heat sensitivity of the EpCSP distinguishes it from the Sertoli cell-derived factor(s) which is heat stable. At present, the cause of the lower $\left[{ }^{3} \mathrm{H}\right]$ thymidine incorporation seen in trypsintreated SCSP is not clear. It is unlikely to be due to possible residual trypsin activity since similar trypsin-STI treatment of the culture medium (DME plus $0.1 \%$ BSA) had no significant effect 
on this parameter. Whether proteolytic products of SCSP or another component of SCSP that is unaffected by trypsin inhibits Leydig cell $\left[{ }^{3} \mathrm{H}\right]$ thymidine incorporation is currently being investigated.

The findings that Leydig cells isolated from rats aged 26 days and 45-90 days had the highest and the lowest values of $\left[{ }^{3} \mathrm{H}\right]$ thymidine incorporation in vitro, respectively, are in accord with the results of in-vivo studies which demonstrate that the rate of increase in the number of Leydig cells in rat testes is highest during the juvenile period (21-28 days) while the lowest rate occurs during pubertal periods ( $\geq 40$ days) (Knorr et al., 1970; Hardy et al., 1989). Also, our observation that preparations of mature Leydig cells incorporated much less $\left[{ }^{3} \mathrm{H}\right]$ thymidine than did the morphologically less mature cells is in agreement with the earlier findings of Abney \& Carswell (1986) and suggests that the age-related differences in basal and SCSP-stimulated $\left[{ }^{3} \mathrm{H}\right]$ thymidine incorporation in the present study are likely to be a reflection of the age-related changes in the proportion of mature Leydig cells in the cell populations studied and not to a possible change in the quality of preparation of the cells from rats aged 16-90 days. Collectively, these findings are consistent with the hypothesis that terminally differentiated Leydig cells may have a reduced ability to proliferate in normal physiological environments (Niemi \& Kormano, 1964; Hardy et al., 1989).

We recognize that the $\left[{ }^{3} \mathrm{H}\right]$ thymidine incorporation assay used in this study explored only the salvage pathway of DNA synthesis. Also, the effect(s) of SCSP on Leydig cell DNA synthesis in vivo is yet to be determined. Nevertheless, three observations made in the course of this study indicate that the SCSP-mediated effects on replicative DNA synthesis in Leydig cells in vitro may reflect physiologically relevant regulatory mechanisms: (1) basal and SCSP-induced $\left[{ }^{3} \mathrm{H}\right]$ thymidine incorporation in the cells both correlated closely with the earlier reported agerelated changes in Leydig cell proliferative capacity in vivo (Niemi \& Kormano, 1964; Knorr et al., 1970; Hardy et al., 1989); (2) hydroxyurea significantly $(P<0.001)$ inhibited SCSPstimulated Leydig cell $\left[{ }^{3} \mathrm{H}\right]$ thymidine incorporation; and (3) our studies of the effect of SCSP on rat Leydig cell proliferation in vitro revealed that SCSP stimulates an increase in Leydig cell number (Fig. 4), confirming the mitogenic effect of SCSP on primary cultures of rat Leydig cells.

The results of this study demonstrate that Sertoli cell secretion of a steroidogenic protein(s) is not regulated by testosterone or FSH. In contrast, the secretion of the mitogenic protein(s) by Sertoli cells is dependent upon FSH and testosterone stimulation. Therefore, these factors are likely to be two distinct Sertoli cell secretory proteins. Interestingly, the putative Leydig cell steroidogenic factor and a mitogen present in rat testicular interstitial fluid have also been demonstrated to be two separate substances (Risbridger et al., 1987; Drummond et al., 1988). The results of the present study are therefore consistent with the hypothesis of a Leydig cell growth factor that is distinct from the secretagogue (Hooker, 1944; Drummond et al., 1988). A speculative explanation for secretion by Sertoli cells of two separate factors instead of one to regulate Leydig cell DNA synthesis and testosterone production is to dissociate these two processes from each other. Such a dissociation could arise from the need to regulate these processes independently to achieve maximum efficiency.

In summary, this study demonstrates for the first time that Sertoli cells secrete a protein(s) $\left(M_{\mathrm{r}} \geq 30000\right)$ which stimulates replicative DNA synthesis in purified preparations of rat Leydig cells in vitro. This protein(s) differs from the previously reported Sertoli cells-secreted protein(s) which stimulates Leydig cell testosterone secretion in vitro with respect to hormonal regulation.

We thank Dr Maozheng Dai for assistance with the electron micrographs; Dr M. H. G. Raj for the gift of testosterone antibody; Dr D. Djakiew for the prostatic cell conditioned media; and NIADDK, NIH, for the gift of oFSH and oLH. This study was supported by NIH grants HD16260 (M.D.); HD23744 (S.W.B.), and a grant from the Mellon Foundation (M.D.). 


\section{References}

Abney, T.O. \& Carswell, L.S. (1986) Gonadotropin regulation of Leydig cell DNA synthesis. Molec. cell. Endocrinol. 45, 157-165.

Aoki, A. \& Fawcett, D.W. (1978) Is there a local feedback from the seminiferous tubules affecting activity of Leydig cells? Biol. Reprod. 19, 144-158.

Ascoli, M. (1981) Characterization of several clonal lines of cultured Leydig tumour cells: Gonadotropin receptors and steroidogeneic responses. Endocrinology 108, 88-95.

Bellve, A.R. \& Zheng, W. (1989) Growth factors as autocrine and paracrine modulators of male gonadal functions. J. Reprod. Fert. 85, 771-793.

Bradford, M.M. (1976) A rapid and sensitive method for the quantitation of microgram quantities of protein using the principle of protein-dye binding. Analyt. Biochem. 72, 248-254.

Byers, S.W., Hadley, M.A., Djakiew, D. \& Dym, M. (1986) Growth and characterization of polarized monolayers of epididymal epithelial cells and Sertoli cells in dual environment culture chambers. $J$. Androl. 7, 59-68.

Chang, C.F. \& Pollard, M. (1977) In vitro propagation of prostate adenocarcinoma cells from rats. Invest. Urol. 14, 331-334.

Chemes, H.E., Rivarola, M.A. \& Bergada, C. (1976) Effect of hCG on the interstitial cells and androgen production in the immature rat testis. J. Reprod. Fert. 46, 279-282.

Christensen, A.K. \& Peacock, C. (1980) Increase in Leydig cell number in the testis of adult rats treated chronically with an excess of human chorionic gonadotropin. Biol. Reprod. 22, 383-391.

Drummond, A.E., Risbridger, G.P., O'Leary, P.C.O. \& de Kretser, D.M. (1988) Alterations in mitogenic and steroidogenic activities in rat testicular interstitial fluid after administration of ethane dimethane sulphonate. J. Reprod. Fert. 83, 141-147.

Duncan, D.B. (1975) T-tests and intervals for comparisons suggested by the data. Biometrics 31, 339-359.

Hadley, M.A., Byers, S.W., Suarez-Quian, C.A., Kleinman, H.K. \& Dym, M. (1985) Extracellular matrix regulates Sertoli cell differentiation, testicular cord formation, and germ cell development in vitro. J. Cell Biol. 101, 1511-1522.

Hardy, M.P., Zirkin, B.R. \& Ewing, L.L. (1989) Kinetic studies on the development of the adult population of Leydig cells in the testes of the pubertal rat. Endocrinology 124, 762-770.

Hooker, C.W. (1944) The postnatal history and function of the interstitial cells of the testis of the bull. Am.J. Anat. 74, 1-37.

Johnson, L., Matt, K.S., Bartke, A., Nguyen, H.B. \& Le, H.T. (1987) Effect of photoperiod on the size of the Leydig cell population and rate of recruitment of Leydig cells in adult Syrian hamsters. Biol. Reprod. 37, 727-738.

Jones, K.H. \& Senft, J.A. (1985) An improved method to determine cell viability by simultaneous staining with fluorescein diacetate-propidium iodide. J. Histochem. Cytochem. 33, 77-79.

Kerr, J.B. \& Sharpe, R.M. (1989) Focal disruption of spermatogenesis in the testis of adult rats after a single administration of human chorionic gonadotropin. Cell Tissue Res. 257, 163-169.

Kerr, J.B. \& Sharpe, R.M. (1985) Follicle-stimulating hormone induction of Leydig cell maturation. Endocrinology 116, 2592-2604.

Klinefelter, G.R., Hall, P.F. \& Ewing, L.L. (1987) Effect of luteinizing hormone deprivation in situ on steroidogenesis of rat Leydig cells purified by a multistep procedure. Biol. Reprod. 36, 769-783.

Knorr, D.W., Vanha-Perttula, T. \& Lipsett, M.B. (1970) Structure and function of rat testis through pubescence. Endocrinology 86, 1298-1304.

de Kretser, D.M. \& Kerr, J.B. (1988) The cytology of the testis. In The Physiology of Reproduction, pp. 837-931. Eds E. Knobil, J. D. Neill, L. L. Ewing, G. S. Greenwald \& C. L. Markert. Raven Press, New York.

Kupio, T., Pelliniemi, L.J. \& Huhtaniemi, I. (1989) Rapid Leydig cell proliferation and luteinizing hormone receptor replenishment in the neonatal rat testis after a single injection of human chorionic gonadotropin. Biol. Reprod. 40, 135-143.

Lauke, H., Behrens, K. \& Holstein, A. (1989) Leydig cell mitoses in human testes bearing early germ cell tumors. Cell Tissue Res. 255, 475-479.

Molenaar, R., de Rooij, D.G., Rommerts, F.F.G. \& Van der Molen, H.J. (1986) Repopulation of Leydig cells in immature rats after selective destruction of the existent Leydig cells with ethylene dimethanesulfonate is dependent on luteinizing hormone and not follicle-stimulating hormone. Endocrinology 118, 2546-2554.

Niemi, M. \& Kormano, M. (1964) Cell renewal in the interstitial tissue of postnatal prepubertal rat testis. Endocrinology 74, 996-998.

Ojeifo, J., Byers, S. \& Dym, M. (1988) In vitro effects of Sertoli cell-secreted protein(s) on testosterone production by highly purified rat Leydig cells. Biol. Reprod. 38 (Suppl. 1), 185, abstr.

Papadopoulos, V., Kamtchouing, P., Drosdowsky, M.A., Hochereau de Reviers, M.T. \& Carreau, S. (1987) Adult rat Sertoli cells secrete a factor or factors which modulate Leydig cell function. J. Endocr. 114, 459-467.

Perrard-Sapori, M.A., Chatelain, P.C., Rogemond, N. \& Saez, J.M. (1987) Modulation of Leydig cell functions by culture with Sertoli cells or Sertoli cellconditioned medium: effect of insulin, somatomedin-C and FSH. Molec. cell. Endocrinol. 50, 193-198.

Risbridger, G.P., Drummond, A.E., Kerr, J.B. \& de Kretser, D.M. (1987) Effect of cryptorchidism on steroidogenesis and mitogenic activities in rat testicular interstitial fluid. J. Reprod. Fert. 81, 617-624.

Skinner, M.K. \& Fritz, I.B. (1985) Testicular peritubular cells secrete a protein under androgen control that modulates Sertoli cell functions. Proc. natn. Acad. Sci. USA 82, 114-118.

Snedecor, G.W. \& Cochran, W.G. (1980) Statistical Methods, 7th edn, p. 215. Iowa State University Press, Ames.

Teerds, K.J., Closset, J., Rommerts, F.F.G., de Rooij, D.G., Stocco, D.M., Colenbrander, B., Wensing, C.J.G. \& Hennen, G. (1989) Effects of pure FSH and 
LH preparations on the number and function of Leydig cells in immature hypophysectomized rats. $J$. Endocr. 120, 97-106.

Teerds, K.J., de Rooij, D.G., Rommerts, F.F.G. \& Wensing, C.J.G. (1988) The regulation of the proliferation and differentiation of rat Leydig cell precursor cells after EDS administration or daily hCG treatment. $J$. Androl. 9, 343-351.

Turner, T.T., Jones, C.E., Howards, S.S., Ewing, L.L., Zegeye, B. \& Gunsalus, G.L. (1984) On the androgen microenvironment of maturing spermatozoa. Endocrinology 115, 1925-1932.

Verhoeven, G. \& Cailleau, J. (1985) A factor in spent media from Sertoli cell-enriched cultures that stimulate steroidogenesis in Leydig cells. Molec. cell. Endocrinol. 40, 57-68.
Wahlstrom, T., Huhtaniemi, I., Hovatta, O. \& Seppala, M. (1983) Localization of luteinizing hormone, follicle-stimulating hormone, prolactin and their receptors in human and rat testis using immunohistochemistry and radioreceptor assay. J. clin. Endocr. Metab. 57, 825-830.

Wawra, E. \& Wintersberger, E. (1983) Does hydroxyurea inhibit DNA replication in mouse cells by more than one mechanism? Molec. cell. Biol. 3, 297-304.

Yoon, D.J., Golimbu, M., Schinella, R., Stein, B., Sklar, C.A. \& David, R. (1987) Immunocytochemical localization of hFSH as an index of Sertoli cell function in the human testis. Acta endocr., Copenh. 116, $333-338$.

Received 6 November 1989 